Georgia State University College of Law Reading Room

Faculty Publications By Year

Faculty Publications

$1-2017$

\title{
Physician Encounters with Human Trafficking: Legal Consequences and Ethical Considerations
}

Jonathan Todres

Georgia State University College of Law, jtodres@gsu.edu

Follow this and additional works at: https://readingroom.law.gsu.edu/faculty_pub

Part of the Health Law and Policy Commons

\section{Recommended Citation}

Jonathan Todres, Physician Encounters with Human Trafficking: Legal Consequences and Ethical Considerations, 19 AMA J. Ethics 16 (2017).

This Article is brought to you for free and open access by the Faculty Publications at Reading Room. It has been accepted for inclusion in Faculty Publications By Year by an authorized administrator of Reading Room. For more information, please contact mbutler@gsu.edu. 


\title{
AMA Journal of Ethics ${ }^{\circledR}$
}

\section{January 2017, Volume 19, Number 1: 16-22}

\section{ETHICS CASE}

\section{Physician Encounters with Human Trafficking: Legal Consequences and Ethical Considerations}

Commentary by Jonathan Todres, JD

\begin{abstract}
There is growing recognition and evidence that health care professionals regularly encounter - though they may not identify — victims of human trafficking in a variety of health care settings. Identifying and responding appropriately to trafficking victims or survivors requires not only training in trauma-informed care but also consideration of the legal and ethical issues that arise when serving this vulnerable population. This essay examines three areas of law that are relevant to this case scenario: criminal law, with a focus on conspiracy; service provider regulations, with a focus on mandatory reporting laws; and human rights law. In addition to imposing a legal mandate, the law can inform ethical considerations about how health care professionals should respond to human trafficking.
\end{abstract}

\section{Case}

Dr. W is an obstetrician working at a women's health clinic in a state that has a high prevalence of human trafficking. A couple arrives at her office, requests a private consultation, and asks whether she keeps information confidential. She assures them that she follows all state and federal laws and regulations regarding the management of protected health information.

The couple informs Dr. W that they "employ and manage" several young women as sex workers. They ask if the clinic would be able to screen their employees for sexually transmitted infections (STIs). They clarify that all services will be compensated; however, they request that no health records be kept for the women. They state that this is necessary to assure the women that they will not be at risk of being arrested because of the nature of their work.

Dr. W feels wary about providing STI testing and managing care for this small group of patients outside of her clinic's standard operating procedure. Dr. W understands that, legally, she is required to maintain health records for all patients, but she is also concerned that this particular underserved and vulnerable group of young women would never receive appropriate gynecological care if their employers find out she keeps 
records for them. The couple promise to facilitate the patients' compliance with STI treatments, if necessary. Dr. W feels torn: she wants to give the women the best care possible while also protecting the community from the possible spread of STIs. But she also worries that, by agreeing to terms set by the couple who employs and manages these women (who might be trafficked and some of whom might be minors), she might be complicit in their exploitation.

\section{Commentary}

There is growing recognition and evidence that health care professionals regularly encounter-though they may not identify-human trafficking victims in various health care settings [1]. Identifying and responding appropriately to trafficking survivors requires not only appropriate clinical training but also consideration of the legal and ethical issues that arise when serving this vulnerable population. This essay examines three legal areas relevant to this discussion: criminal law, with a focus on conspiracy; service provider regulations, with a focus on mandatory reporting laws; and human rights law. In addition to imposing a legal mandate, the law in these areas can inform health care professionals' ethical considerations in responding to human trafficking during clinical encounters, at an institutional level, and as a profession.

\section{Conspiracy Law and Health Care for Sex Trafficking Victims}

Although it might seem strange to raise the specter of conspiracy charges with regard to a well-intentioned physician, an analysis of conspiracy law can illuminate some of the ethical issues in this case. Criminal conspiracy has four elements: an objective, a plan showing the means to accomplish that objective, an agreement between two or more people to cooperate to achieve that objective, and an overt act in furtherance of the crime [2]. Here, the couple who operates a prostitution business has set out the plan, and an act in furtherance of the crime - whether it is sex trafficking or a related charge such as pimping (living off the proceeds of the prostitution of another person) [3] or pandering (recruiting and retaining a person in prostitution) [4] - appears imminent. The critical question, from a legal perspective, is whether $\mathrm{Dr}$. W and the couple have entered into an agreement to achieve the criminal objective.

To determine whether a person has agreed to conspire to commit a crime, the law asks whether: (1) she knows of the crime and (2) either (a) she intends to participate, (b) the crime is very harmful, or (c) she has a "stake" in the crime [5].

For the first element, given what the couple has conveyed to Dr. W-that they run a prostitution ring - she could not plausibly deny knowledge of a crime. Prostitution is illegal, as are operating a prostitution business and sex trafficking $[3,4,6,7]$. If minors are among those individuals "employed" by the couple, the couple would be running a child sex trafficking ring - they are engaged in recruiting, harboring, and maintaining individuals to engage in commercial sex acts (when a child is the victim, a prosecutor 
does not need to show force, fraud, or coercion was used by the defendant, as the consent of a minor is irrelevant for the crime of sex trafficking) [7]. If the couple uses force, fraud, or coercion to keep adults in their control, they likely are engaged in sex trafficking of the adult women as well.

Next, although it may be fair to conclude that the doctor does not intend to participate in the crime of sex trafficking, or have the purpose that the crime occur, the other two options for the second element put the physician's actions in more doubt. Courts have stated that "when a serious crime is involved, a supplier of goods or services may be 'held liable [for conspiracy] as a participant on the basis of knowledge alone,' even if 'it cannot reasonably be said that the supplier has a stake in the venture or has acquired a special interest in the enterprise'" $[8,9]$. For example, a California appellate court stated that the operator of a telephone answering service might be able to be charged with conspiracy in an extortion, narcotics distribution, or counterfeit money scheme based on his knowledge that the telephone service was being used to facilitate one of these crimes, even if he did not intend to participate in the crime [10].

Human trafficking seems to be an obvious example of a crime that is very harmful. The harm inflicted on its victims can be life threatening [11]. Even if a court would be reluctant to convict a defendant (e.g., physician) on knowledge alone based on the crime's severity, the question remains whether the physician in this case has a "stake" in the enterprise. That element can be met when (1) the defendant charges the criminals (here, the couple) inflated rates, (2) the goods or services have no legitimate use, or (3) there is no legitimate use for the volume of goods supplied [9]. If Dr. W is paid more than her usual rates, she would have a stake in the enterprise. If she charges her usual rates, the case against her is not as strong. It might depend in part on whether she is paid "under the table." If she agrees to keep no patient records, for example, she might not record the payments. Proceeds received "off the books" might arguably give Dr. W a stake in the enterprise.

There are legitimate concerns about prosecuting a physician for conspiracy in a case like this one. Unlike cases involving telephone operators and others whose involvement may be more clearly motivated by profit, the physician aims to provide needed care. Equally important is what a successful prosecution might mean in terms of implications for clinicians' practice. What would physicians be required to inquire about-from a legal and ethical standpoint-beyond what is necessary to treat a patient from a clinical standpoint? Could a threat of conspiracy charges have a chilling effect on patientphysician communications? And, relevant to this case, would physicians be reluctant to treat certain vulnerable populations out of fear that doing so might inadvertently involve them in a criminal conspiracy? Ultimately, these questions and their broader policy implications weigh against the view that a physician such as Dr. W should be charged with conspiracy to commit sex trafficking or related crimes, unless there is clear evidence 
that the physician is charging excessive rates and has little interest in helping these patients.

Although it might not be appropriate to proceed with conspiracy charges against Dr. W, it could be argued that, by providing care, Dr. W would be helping the couple to continue using these women and girls in their prostitution business. Therefore, examining the case through a conspiracy law lens highlights a critical ethical question: Should the physician's participation in this endeavor be viewed as enabling the exploitation of these women and girls?

\section{Clinicians' Duty to Report Suspected Sex Trafficking or Sexual Exploitation of Minors}

If any of the young women controlled by the couple are minors, Dr. W might have a legal duty to report these cases. All fifty states have mandatory reporting laws for child maltreatment $[12,13]$. Health care professionals typically are deemed mandatory reporters and must report suspected abuse and neglect of children (under mandatory reporting laws, physicians or the hospital typically must report the case to child protective services, law enforcement, or both) [13]. In the past several years, some states have expanded their mandatory reporting laws to cover human trafficking (as of December 2015, 14 states had included sex trafficking as reportable acts, and ten of those also included labor trafficking) [13]. If a physician practiced medicine in one of those states and an underage girl who was part of this scheme presented with symptoms that suggest she might be a sex trafficking victim, the physician would be violating the law by failing to report this case. However, states that have not expressly included sex trafficking in their mandatory child abuse reporting laws still include "sexual abuse" and/or "sexual exploitation" as reportable maltreatment [13]. Because symptoms of sexual abuse, sexual exploitation, and sex trafficking can overlap, it would be difficult for a physician to argue that a patient shows signs of being a victim of sex trafficking, but not sexual exploitation or sexual abuse. A physician's recognition of sexual abuse symptoms or similar harms that are possibly the result of sex trafficking should trigger his or her reporting of the case. Said another way, if, based on his or her examination of a patient, a physician suspects a child has been subjected to sexual abuse, it would be a troubling result if we allowed the physician to not report solely because the physician suspects that the abuse occurred in the context of money or food being exchanged for sex.

The physician's duty to report if she suspects that a minor is being sexually abused or trafficked is supported by the purpose of mandatory reporting laws, which is to spur intervention in appropriate cases to prevent further harm to children. If a physician continues to provide health care services while remaining silent about the continued sexual exploitation of a child, her actions would fail to achieve the goal of reducing harm to children. 
Research shows that some health care professionals do not report all suspected cases of child maltreatment [1]. Reasons for not reporting include concerns that a report will not help the child or family, may result in further harm, or could chill future communication between patient and physician [1]. Clinicians' concerns about mandatory reporting laws must be taken seriously, particularly because in many settings, social service agencies may not have the capacity to handle additional cases or might lack specialized training to serve child trafficking survivors [1]. To be clear, however, the legal and ethical obligation of health care professionals in these scenarios is to seek help for the child, not to return her to her abusers. The response to physicians' concerns about mandatory reporting laws must be to address them at a policy level by strengthening social service agencies' capacities to help at-risk and exploited children rather than to allow clinicians and others who work with children to decide for themselves on a case-by-case basis whether and when to comply with the law.

\section{Health Care Professionals' Obligations under Human Rights Law}

Human rights law is also relevant in this context, even if its legal authority in the United States is more limited (although the United States has supported the development of human rights treaties historically, it has been slow to ratify them once they are adopted) [14]. There is no question that human rights law prohibits human trafficking $[15,16]$. For example, in the Rome Statute of the International Criminal Court, the definition of a "crime against humanity" includes "enslavement" which itself is defined as including "trafficking in persons, in particular women and children" [17]. Beyond treaty law, given that slavery violates customary international law [18], there is an argument that human trafficking - the experience of which is akin to enslavement for many victims - is also prohibited under customary international law, meaning that prohibition applies to every country, regardless of whether it has ratified an applicable treaty.

Physician facilitation of human rights violations has long been debated in other contexts, most notably with interrogation of prisoners of war or enemy combatants [19]. Should physicians participate in actions that might rise to the level of torture? Are they ensuring patients' survival and well-being or merely enabling harm? A similar question could be asked here: Should a physician participate in —and accept compensation for aiding - a scheme that involves the sexual exploitation of young women and girls? The answer must be no. The desire to assist vulnerable patients is understandable, as is the concern that the patients' situation might become worse if the physician refuses to offer care. But there are other options in this scenario, not least of which is that the physician can ensure the couple is reported to law enforcement so police can investigate.

\section{Conclusion}

Evaluating Dr. W's dilemma using a conspiracy law framework highlights the idea that her participation, while perhaps well-meaning, may actually facilitate exploitation.

Mandatory reporting laws indicate that $\mathrm{Dr}$. W has a duty to report any minors 
"employed" by the couple. Finally, human rights law reminds us of every person's duty not to participate in human rights violations, however well-intentioned we might think our actions are. Ultimately, the ethical challenges raised by this case, combined with the growing recognition that many health care professionals encounter human trafficking [20], should prompt the medical profession to develop guidelines for responding to all forms of human trafficking. Requiring relevant health care professionals to be trained in identifying and treating trafficking survivors would not only help reduce and perhaps even avoid harm, but also strengthen the broader responses to human trafficking. A multisector response is needed to prevent, identify, and respond effectively to human trafficking, and health care professionals like Dr. W have critical roles to play.

\section{References}

1. Institute of Medicine; National Research Council. Confronting Commercial Sexual Exploitation and Sex Trafficking of Minors in the United States. Washington, DC: National Academies Press; 2013.

2. 15A CJS Conspiracy sec 116 (2016).

3. 73 CJS Pimping sec 41 (2016).

4. 73 CJS Pandering sec 27 (2016).

5. Weisberg R. Reappraising complicity. Buffalo Crim Law Rev. 2000;4(1):217-281.

6. DeCoua K. US social policy on prostitution: whose welfare is served? New Engl J Crim Civ Confin. 1998;24:427-453.

7. 18 USC sec 1589 (2016).

8. People v Maldonado, 2008 WL 401589, 1, 3 (Ca Ct App).

9. People v Lauria, 251 Cal App 2d 471, 480 (1967)

10. People v Lauria, 480-481.

11. Todres J. Moving upstream: the merits of a public health law approach to human trafficking. North Carol Law Rev. 2011;89(2):447-506.

12. Child Welfare Information Gateway. Mandatory reporters of child abuse and neglect. https://www.childwelfare.gov/pubPDFs/manda.pdf. Accessed November 9, 2016.

13. Todres J. Can mandatory reporting laws help child survivors of human trafficking? Wis L Rev Forward. 2016:69-78. http://wisconsinlawreview.org/wpcontent/uploads/2016/04/Todres-Final.pdf. Accessed September 13, 2016.

14. Koh HH. The future of Lou Henkin's human rights movement. Columbia Human Rights Law Rev. 2007;38:487-498.

15. Protocol to Prevent, Suppress and Punish Trafficking in Persons, Especially Women and Children, Supplementing the United Nations Convention Against Transnational Organized Crime. http://www.osce.org/odihr/19223?download=true. Effective December 25, 2003. Accessed November 17, 2016.

16. Optional Protocol to the Convention on the Rights of the Child on the Sale of Children, Child Prostitution and Child Pornography. 
http://www.ohchr.org/Documents/Professionallnterest/crc-sale.pdf. Effective January 18, 2002. Accessed November 17, 2016.

17. Rome Statute of the International Criminal Court. Hague, The Netherlands: International Criminal Court; 2011:4. https://www.icccpi.int/NR/rdonlyres/ADD16852-AEE9-4757-ABE79CDC7CF02886/283503/RomeStatutEng1.pdf. Accessed November 16, 2016.

18. American Law Institute. Restatement of the Law (Third) The Foreign Relations Law of the United States. St. Paul, MN: American Law Institute Publishers; 1987:sec 702.

19. Miles SH. Oath Betrayed: Torture, Medical Complicity, and the War on Terror. Berkeley, CA: University of California Press; 2009.

20. Lederer $L J$, Wetzel CA. The health consequences of sex trafficking and their implications for identifying victims in healthcare facilities. Ann Health Law. 2014;23(1):61-91.

Jonathan Todres, JD, is a professor of law at Georgia State University College of Law in Atlanta. His research focuses on children's rights issues. He has authored numerous publications on child trafficking and related forms of child exploitation.

\section{Related in the AMA Journal of Ethics}

Caring for the Trafficked Patient: Ethical Challenges and Recommendations for Health Care Professionals, January 2017

Decreasing Human Trafficking through Sex Work Decriminalization, January 2017 Liability for Failure to Report Child Abuse, December 2007

Mandatory Reporting of Human Trafficking: Potential Benefits and Risks of Harm, January 2017

Should US Physicians Support the Decriminalization of Commercial Sex?, January 2017 Who is in Your Waiting Room? Health Care Professionals as Culturally Responsive and Trauma-Informed First Responders to Human Trafficking, January 2017

The people and events in this case are fictional. Resemblance to real events or to names of people, living or dead, is entirely coincidental.

The viewpoints expressed in this article are those of the author(s) and do not necessarily reflect the views and policies of the AMA.

\section{Copyright 2017 American Medical Association. All rights reserved.}

